\title{
Analiza porównawcza osiągnięć szkolnych trzynastolatków korzystających z implantu ślimakowego wszczepionego im przed ukończeniem 3 roku życia i słyszących rówieśników
}

\section{Comparative analysis of academic achievements of 13-year olds with cochlear implants provided before the age of 3 and their hearing peers}

\author{
Małgorzata Zgoda, Artur Lorens, Anita Obrycka, Joanna Putkiewicz-Aleksandrowicz, \\ Henryk Skarżyński \\ Instytut Fizjologii i Patologii Słuchu, Światowe Centrum Słuchu, Warszawa/Kajetany \\ Adres autora: Małgorzata Zgoda, Światowe Centrum Słuchu, Zakład Implantów i Percepcji Słuchowej, \\ ul. Mokra 17, Kajetany, 05-830 Nadarzyn, e-mail: m.zgoda@ifps.org.pl
}

\section{Streszczenie}

Wstęp: Uwarunkowania edukacji osób niesłyszących zmieniają się pod wpływem stale udoskonalanych implantów ślimakowych. Zmniejsza się udział uczniów z głęboką wadą słuchu w szkolnictwie specjalnym. Doniesienia naukowe potwierdzają możliwość uzyskania prawidłowego poziomu rozwoju słuchowego i językowego w przypadku wczesnego stosowania implantów ślimakowych u dzieci z głuchotą prelingwalną. Nieliczne są badania, które w sposób zobiektywizowany dokumentowałyby udział dzieci korzystających z implantów ślimakowych w szkolnictwie ogólnodostępnym i integracyjnym oraz osiągane przez te dzieci wyniki w nauce.

Cel: Celem nadrzędnym pracy było określenie rozkładu miejsca realizacji obowiązku szkolnego przez dzieci z głębokim niedosłuchem, korzystające $\mathrm{z}$ implantu ślimakowego wszczepionego im przed ukończeniem 3 roku życia, w szkołach ogólnodostępnych i integracyjnych oraz specjalnych, a także zbadanie, ile dzieci przystąpiło do sprawdzianu na zakończenie nauki w szkole podstawowej zgodnie z rozporządzeniem Ministra Edukacji Narodowej z dnia 30 kwietnia 2007 r. na takich samych zasadach jak dzieci bez dysfunkcji. Drugim celem było porównanie osiągnięć szkolnych dzieci korzystających z implantu ślimakowego z wynikami dzieci bez dysfunkcji.

\begin{abstract}
Materiał i metody: Do oceny porównawczej osiągnięć szkolnych dzieci, którym wszczepiono implant ślimakowy przed ukończeniem trzeciego roku życia, wykorzystano retrospektywne badanie obserwacyjne, kliniczno-kontrolne. Do grupy badanej zakwalifikowano 22 dzieci, które urodziły się w roku 2000 i którym w Instytucie Fizjologii i Patologii Słuchu wszczepiono implant ślimakowy przed ukończeniem 3 roku życia. Miarą przyjętą w badaniu osiągnięć szkolnych był wynik powszechnego sprawdzianu na zakończenie szkoły podstawowej z roku 2013.
\end{abstract}

Wyniki: W badanej grupie 16 dzieci realizowało obowiązek szkolny w szkołach ogólnodostępnych i integracyjnych (73\%), a 6 w szkołach specjalnych (27\%). Z tego 32\% dzieci przystąpiło do sprawdzianu na zakończenie nauki w szkole podstawowej na takich samych zasadach jak dzieci bez dysfunkcji. Dzieci te osiągnęły wyniki sprawdzianu odpowiadające co najmniej 5 staninowi dla dzieci bez dysfunkcji.

\footnotetext{
Wnioski Udział dzieci prelingwalnie głuchych implantowanych przed 3 rokiem życia w szkolnictwie ogólnodostępnym i integracyjnym przeważa nad pobieraniem przez te dzieci nauki w szkolnictwie specjalnym. Dzieci, które zgodnie z decyzją rodziców przystępują do sprawdzianu na warunkach takich samych jak dzieci bez dysfunkcji, uzyskują satysfakcjonujące wyniki sprawdzianu na zakończenie nauki w szkole podstawowej. Zebrane dane z wykorzystaniem badania obserwacyjnego kliniczno-kontrolnego umożliwiły przeprowadzenie pierwszych analiz dotyczących korzyści z interwencji medycznej, polegającej na wczesnej implantacji u dzieci głuchych w kontekście osiąganych przez nie wyników w nauce po ponad 10 latach korzystania z systemu implantu ślimakowego.
}

Słowa kluczowe: dziecko • implant ślimakowy • szkoła 


\section{Abstract}

Introduction: Cochlear implants change historical conditioning of education of deaf persons. The proportion of students with profound hearing loss in special education settings diminishes. Research reports confirm the possibility of achieving normal level of development of hearing and language in the cases of early cochlear implantation in prelingually deaf children. Only a few studies objectively document the participation of children using cochlear implants in mainstream education and academic achievements of these children.

Aim: The general objective of the present study was to determine the distribution of the realization of compulsory education by children with profound hearing loss provided with cochlear implants before the age of three between mainstream, integrated and special schools, and to check how many children took a school competency test at the end of a primary school (test carried out in accordance with the Decree of the Polish Minister of National Education of 30 April 2007) at the same conditions as normally hearing children. The second objective was to compare the academic achievements of children using cochlear implants and children with no dysfunctions.

Material and methods: The comparative analysis of the academic achievements of children provided with cochlear implants before the age of three was based on retrospective observational clinical follow-up study. The study group included 22 children born after 2000, provided with cochlear implants in the Institute of Physiology and Pathology of Hearing before the age of three. A measure used for the evaluation of academic achievements was the results of school competency test at the end of a primary school in 2013.

Results: In the study group, 16 children attended mainstream and integrated schools (73\%) and 6 - special schools (27\%). From the whole group, $32 \%$ of children took a school competency test in accordance with the Decree of the Polish Minister of National Education of 30 April 2007 on the same conditions as children without dysfunctions. Results obtained by these children were adequate to those of children without dysfunctions at least in the $5^{\text {th }}$ stanine.

Conclusions: The participation of the prelingually deaf children implanted before the age of three in mainstream and integrated schools is higher than in special schools. Children, whose parents decided that they should take a school competency test at the end of a primary school on the same conditions as children without dysfunctions achieve satisfactory results in this test. Collected observation data provided a unique opportunity to perform the first comparative analyses of academic achievements of deaf children in the 10 -year period of the cochlear implants use.

Key words: child $\bullet$ cochlear implant $\bullet$ school

\section{Wstęp}

Wykształcenie i pozycja na rynku pracy odgrywają kluczową rolę w kształtowaniu „dobrostanu” psychologicznego i społeczno-ekonomicznego osób niepełnosprawnych. Niestety, jak pokazują wyniki badań oraz dane statystyczne, w Polsce wskaźniki wykształcenia oraz aktywności zawodowej osób niepełnosprawnych są znacznie niższe niż w innych krajach europejskich [1]. Współcześnie, cytując za Golinowską (2000), „wiedza jest warunkiem uruchomienia i absorpcji czynników wzrostu, jak i szerzej rozwoju ludzkiego, bo człowiek wykształcony ma większe możliwości wyboru i szansę rozwoju swoich talentów oraz zaspokojenia aspiracji" [2]. Umiejętności szkolne nabywane na początkowym etapie edukacji stanowią podwaliny do dalszych sukcesów.

Niewłaściwie funkcjonujący układ słuchowy oraz niewykształcona sprawność percepcyjna w przypadku głuchoty czy niedosłuchu prelingwalnego wpływają bezpośrednio na występowanie zaburzeń mowy, nabywanie kompetencji językowej i komunikacyjnej [3]. Kompetencje językowe warunkują funkcjonowanie dziecka głuchego w szkole i jego osiągnięcia w nauce [4].

Implant ślimakowy jest elektroniczną protezą ucha wewnętrznego. Jego działanie polega na stymulacji elektrycznej zakończeń nerwu słuchowego, co pozwala na ominięcie uszkodzonych komórek słuchowych ucha wewnętrznego, których funkcja zastępowana jest stymulacją elektryczną [5]. Umożliwia to odbiór bodźców dźwiękowych, w tym mowy.

W Polsce tę metodę leczenia głuchoty zapoczątkował H. Skarżyński w 1992 roku [6]. Od tego czasu w Polsce wszczepiono implant ślimakowy kilku tysiącom osób, z czego około połowę stanowiły dzieci. Amerykańska Agencja Żywności i Leków podała, że w 2012 roku liczba osób na świecie, którym wszczepiono implant ślimakowy, przekroczyła 324 200. Metoda ta jest obecnie standardową procedurą stosowaną w leczeniu różnych typów niedosłuchu.

Raportowane w roku 1982 przez Eisenberga i House'a ze Stanów Zjednoczonych pierwsze doświadczenia w grupie 12 dzieci w wieku od 3,5 do 17 lat, którym wszczepiono jednokanałowe implanty ślimakowe, potwierdzały możliwość odbioru dźwięków za pośrednictwem stymulacji elektrycznej, co z kolei przekładało się na korzyści socjalne oraz zmianę jakości głosu [7]. W pierwszych latach realizacji Polskiego Programu Implantów (od 1992 r. do 1998 r.) prof. Skarżyński przeprowadził operacje u 55 dzieci w wieku od 2,4 do 17 lat, przy czym średnia wieku w momencie operacji wynosiła 9,2 roku [8].

W początkowych okresach rozwoju pediatrycznych programów implantów ślimakowych większość dzieci diagnozowana w kierunku wszczepienia implantu miała 
ukończone 4 lata. Funkcjonujące od lat sześćdziesiątych $\mathrm{XX}$ wieku pojęcie okresu krytycznego dla rozwoju mowy, spopularyzowane przez Lenneberga, znalazło w latach osiemdziesiątych swoje odzwierciedlenie w badaniach neurobiologów [9]. Ujawniły one zależność między wiekiem, w którym wystąpiło uszkodzenie słuchu, a konsekwencjami deprywacji słuchowej [10]. Stwierdzono, że gdy pojawia się ona w początkowym okresie rozwojowym, to powoduje nieodwracalną utratę możliwości prawidłowego funkcjonowania układu słuchowego. Wyniki te stanowiły podstawę do obniżenia wieku dzieci kwalifikowanych do operacji, początkowo do 2 roku życia. Zwiększająca się wiedza na temat wpływu stymulacji organów sensorycznych na kształtowanie się nowych połączeń neuronalnych w mózgu dziecka oraz wpływu wczesnej deprywacji sensorycznej (głuchota wrodzona bądź wcześnie nabyta) na powstawanie zmian w funkcjonowaniu drogi słuchowej spowodowała obniżenie wieku kwalifikacji do wszczepienia implantu do pierwszego roku życia. Celem tych działań było zapewnienie dziecku z wadą słuchu dostępu do dźwięków w okresie krytycznym dla rozwoju słuchu i mowy [11].

Prowadzone prace naukowo-badawcze wykazały, że układ nerwowy jest w pewnym stopniu plastyczny przez całe życie człowieka, jednak dynamika tej plastyczności jest największa w okresie rozwoju, a szczególnie w pierwszych dwóch latach życia. Dotyczy to także procesu nabywania umiejętności językowych i rozwoju mowy [12]. Prace prowadzone pod koniec lat dziewięćdziesiątych ubiegłego wieku wskazywały, że implantowanie dzieci niesłyszących w okresie największej plastyczności mózgu umożliwia im rozwijanie mowy w sposób zbliżony do etapów rozwoju mowy dziecka słyszącego, stwarzając warunki do pełniejszego jej rozwoju [13-19]. Przełomowe stały się badania nad plastycznością mózgu u dzieci głuchych pod kątem możliwości zachowania funkcji słuchowych kory mózgowej po wieloletnim okresie braku stymulacji. Wynikało z nich, że przez 3 lata ośrodki słuchowe w korze mózgowej nie ulegają zmianom degeneracyjnym w wyniku braku stymulacji dźwiękowej [20,21]. Badania te przyczyniły się do wyznaczenia granicy czasowej dla optymalnego zakresu plastyczności drogi słuchowej, jednoznacznie potwierdzając istnienie okresu krytycznego dla rozwoju słuchowego dziecka i konieczność implantacji w wieku 3,5-4 lata, a najlepiej przed drugim rokiem życia [22]. Wczesna stymulacja słuchowa uzyskana przez zastosowanie implantu ślimakowego ogranicza reorganizację poddanego deprywacji, niedojrzałego obszaru słuchowego w mózgu, pobudzając zarówno rozwój słuchowy, jak i rozwój mowy werbalnej [23]. Wczesne zastosowanie implantu ślimakowego pozwala na uzyskanie rozwoju percepcji słuchowej zbliżonego do tego, jaki prezentują dzieci prawidłowo słyszące [24-26]. Obecne kryteria kwalifikacji przyjęte w Instytucie Fizjologii i Patologii Słuchu (IFPS) umożliwiają implantowanie dzieci znacznie poniżej 12 miesiąca życia [27].

Decyzja o poddaniu dziecka operacji wszczepienia implantu ślimakowego jest najczęściej motywowana pragnieniem rodziców, by ich niesłyszące dziecko mogło rozwinąć mowę i język foniczny, zdolność komunikowania się werbalnego oraz by miało możliwość uczęszczania do szkoły razem $\mathrm{z}$ rówieśnikami i uzyskiwania osiągnięć szkolnych podobnych do dzieci słyszących. Jak podaje
Kobosko (2014), edukacja szkolna w warunkach integracji ze słyszącymi dziećmi staje się celem słyszących rodziców dzieci głuchych od samego początku, czyli na ogół od momentu zdiagnozowania głuchoty [3]. Zadaniem obecnie prezentowanego badania jest weryfikacja, czy cel ten jest realistyczny.

Jak podaje m.in. Kobosko, rodzice uznają niejednokrotnie, że edukacja dziecka głuchego razem ze słyszącymi rówieśnikami jest najlepszym rozwiązaniem. Autorka podkreśla również, że integracja społeczna, podobnie jak integracja edukacyjna, ma ogromny wpływ na to, czy dziecko niepełnosprawne odniesie sukces, tj. będzie efektywnie realizowało naukę w szkole, koegzystując i współpracując $\mathrm{w}$ grupie osób pełnosprawnych.

Według Summerfield i Marshalla (1999) do korzyści $\mathrm{w}$ okresie pięciu kolejnych lat po interwencji medycznej w postaci implantu ślimakowego zalicza się poprawę osiągnięć szkolnych [28]. Osiągnięcia szkolne to pojęcie najczęściej określające korzystne zmiany zarówno w sferze instrumentalnej ucznia (w zasobach informacji, w sprawnościach intelektualnych, umiejętności korzystania $\mathrm{z}$ tych informacji w działaniu), jak i w sferze kierunkowej (w motywacji do działania, w aspiracjach, uczuciach oraz postawach) [29]. Już Góralówna (1992) zwracała uwagę na trudność w porównywaniu wyników szkolnych dzieci głuchych uczących się w szkołach specjalnych z poziomem wiedzy rówieśników słyszących, uczących się w szkołach ogólnodostępnych [30]. Badania skupiające się na szeroko rozumianym pojęciu osiągnięć szkolnych dzieci korzystających $\mathrm{z}$ implantu ślimakowego $\mathrm{w}$ porównaniu $\mathrm{z}$ osiągnięciami prawidłowo słyszących rówieśników są nieliczne. Spencer i współautorzy (2004) zbadali 15 dzieci implantowanych (wiek dzieci w momencie operacji wynosił 2,4-12,7) standaryzowanym testem osiągnięć szkolnych i wykazali, że dzieci te uzyskują wyniki szkolne porównywalne lub wyższe od tych uzyskiwanych przez słyszących rówieśników [31].

Inni badacze wskazują na występowanie różnic między wynikami szkolnymi dzieci słyszących i tych korzystających z implantu ślimakowego. Punch i Hyde (2011) przeprowadzili badania ankietowe, w których wzięło udział 151 nauczycieli pracujących z dziećmi korzystającymi z implantu ślimakowego jedno- bądź obustronnie. $Z$ badań tych wynikało między innymi, że około $60 \%$ nauczycieli nie zgadzało się ze stwierdzeniem, iż dzieci korzystające $\mathrm{z}$ implantu uzyskują wyniki w zakresie czytania, pisania oraz umiejętności matematycznych na poziomie oczekiwanym dla ich wieku metrykalnego. Nauczyciele szacowali, że osiągnięcia szkolne $70 \%$ dzieci korzystających z systemu implantu są poniżej średniej klasowej [32]. Podobnie badanie przeprowadzone przez Mukari i współpracowników (2007) wykazało, że 56,25\% badanej grupy, którą stanowiły dzieci implantowane, osiągało wyniki poniżej średniej wyznaczonej dla dzieci ze słuchem prawidłowym [33].

Wśród badań polskich tylko nieliczne prace eksplorują zagadnienie osiągnięć szkolnych dzieci korzystających z systemu implantu ślimakowego. Kosmalowa i Szuchnik (2000) objęły badaniami 14 dzieci zaopatrzonych w implanty ślimakowe w różnym okresie życia; w momencie operacji najstarsze dziecko w tej grupie miało 11 lat i 2 miesiące, najmłodsze 
4 lata i 5 miesięcy. W badaniach ankietowych nauczyciele, posługując się pięciopunktową skalą, dobrze ocenili, przyznając oceny od 4 do 5 , u większości badanych uczniów: sprawność czytania u 8 uczniów, czytanie ze zrozumieniem u 7 uczniów, sprawność pisania u 10 uczniów, pisanie zgodne z zasadami ortografii u 7 uczniów. Większość dzieci w tych zakresach była - zdaniem nauczycieli - co najmniej na przeciętnym poziomie klasy [34]. Badana grupa dzieci nie była porównywana $\mathrm{z}$ dziećmi $\mathrm{z}$ normą słuchową, a ocena była szacowana subiektywnie przez nauczycieli. W badanej grupie były dzieci implantowane w późnym wieku.

A zatem pomimo tego, że badania naukowe potwierdzają możliwość uzyskania prawidłowego poziomu rozwoju słuchowego i językowego w przypadku wczesnego stosowania implantów ślimakowych u dzieci z głuchotą prelingwalną, nieliczne są doniesienia, które w sposób zobiektywizowany dokumentowałyby osiągane przez te dzieci wyniki szkolne. W historycznych badaniach Kirejczyka z roku 1962 i 1967, dotyczących nauczania dzieci głuchych w szkołach dla słyszących, autor stwierdzał, że „(..) jedynie wyjątkowo zdolne dzieci głuche, bez uprzedniego przygotowania, mogą przy dużym wysiłku pokonać napotykane $\mathrm{w}$ tej nauce trudności, zaadaptować się do warunków szkoły normalnej, opanować przewidziany programem materiał i kończyć te szkoły" [35].

Uwarunkowania edukacji osób niesłyszących zmieniają się dzięki coraz doskonalszym technologiom umożliwiającym poprawę słyszenia. Nauczyciele spotykają obecnie w swojej pracy uczniów niesłyszących, korzystających z elektronicznej protezy słuchu, która nie tylko umożliwia im słyszenie, lecz także sprzyja rozwojowi ich procesów poznawczych [36]. Technologia ta nie przywraca stanu pełnego zdrowia, ale stosowana w odpowiedni sposób pozwala na osiąganie zdolności percepcyjnych wcześniej niedostępnych dla osób niesłyszących.

Celem nadrzędnym pracy było określenie rozkładu miejsca realizacji obowiązku szkolnego przez dzieci z głębokim niedosłuchem korzystające $\mathrm{z}$ implantu ślimakowego wszczepionego im przed ukończeniem 3 roku życia w szkołach ogólnodostępnych i integracyjnych oraz specjalnych, a także zbadanie, ile dzieci przystąpiło do sprawdzianu na zakończenie nauki w szkole podstawowej, zgodnie $\mathrm{z}$ rozporządzeniem Ministra Edukacji Narodowej z dnia 30 kwietnia 2007 r., na takich samych zasadach jak dzieci bez dysfunkcji. Drugim celem było porównanie osiągnięć szkolnych dzieci korzystających z implantu ślimakowego $\mathrm{z}$ wynikami dzieci bez dysfunkcji.

\section{Materiał i metody}

Rodzaj badania

Do oceny porównawczej osiągnięć szkolnych dzieci, którym wszczepiono implant ślimakowy przed ukończeniem trzeciego roku życia, wykorzystano retrospektywne badanie obserwacyjne, kliniczno-kontrolne. Badanie kliniczno-kontrolne jest analizą retrospektywną polegającą na wybraniu grupy osób z daną cechą (pacjenci - dzieci wcześnie implantowane). W badaniach porównuje się ekspozycję na działanie czynnika (sprawdzian na zakończenie nauki w szkole podstawowej) w grupie pacjentów i w grupie osób zdrowych (uczniowie ze słuchem prawidłowym) na podstawie zgromadzonej wcześniej dokumentacji medycznej [37].

Wybrany rodzaj badania był jedynym możliwym do zastosowania $\mathrm{z}$ uwagi na nadal stosunkowo rzadkie testowanie dzieci $\mathrm{z}$ implantami ślimakowymi tym samym formularzem sprawdzianu, który przeznaczony jest dla dzieci bez dysfunkcji. Ponadto prospektywny - eksperymentalny rodzaj badania wymagałby wieloletniej obserwacji, gdyż sprawdzian osiągnięć szkolnych odbywał się po ok. 10 latach od wszczepienia implantu. $Z$ powodów etycznych brak jest również możliwości prowadzenia randomizacji. Dobór losowy do grupy dzieci wcześnie implantowanych i późno implantowanych naraziłby, zgodnie z ówczesnym stanem wiedzy, dzieci z grupy późno implantowanych na możliwość uzyskania gorszych wyników [38].

\section{Wyłonienie grupy badawczej}

Doniesienia naukowe oraz obserwacje własne prowadzone w Instytucie Fizjologii i Patologii Słuchu doprowadziły do zmiany udziału poszczególnych grup wiekowych w populacji dzieci zaimplantowanych w IFPS. W latach 2000-2001 podział ze względu na wiek przedstawiał się następująco: dzieci 0-3 lata - 25\%, 3-5 lat - 41\%, 5-8 lat - 19\%, 8-15 lat - 15\% [39]. Badanie przeprowadzone w ramach niniejszej pracy miało miejsce w czerwcu 2013 roku. Z grupy pacjentów implantowanych w IFPS wytypowano 883 dzieci, które miały mniej niż 3 lata $w$ momencie operacji. Zgodnie $\mathrm{z}$ wiekiem metrykalnym dzieci kończące naukę w szkole podstawowej w roku 2013 urodziły się w roku 2000. Zidentyfikowano 23 dzieci spełniających oba warunki włączenia do grupy badanej. Ze względu na brak kontaktu $\mathrm{z}$ rodziną jednego $\mathrm{z}$ dzieci zostało ono wykluczone $\mathrm{z}$ badania. Ostatecznie grupa liczyła 22 dzieci. Wśród tych dzieci sprawdzian na formularzu dla dzieci bez dysfunkcji pisało 7 dzieci $(n=7)$. W grupie badanej były cztery dziewczynki i trzech chłopców. Wiek w momencie operacji wszczepienia implantu w badanej grupie zawierał się w przedziale od 1,5 roku do 2,6 lat. U dwojga dzieci wada słuchu miała podłoże genetyczne, u pozostałych przyczyna była nieznana. Dzieci miały wszczepiony implant ślimakowy do jednego ucha. Ze względu na brak funkcjonalnych resztek słuchowych żadne nie korzystało $\mathrm{z}$ aparatu słuchowego na uchu nieimplantowanym.

Grupę kontrolną stanowiła populacja dzieci polskich $(\mathrm{n}=350614)$, która w roku 2013 przystąpiła do sprawdzianu na zakończenie edukacji w szkole podstawowej na arkuszu egzaminacyjnym dla uczniów bez dysfunkcji i uczniów z dysleksją rozwojową (S-1-132).

\section{Metody}

Miarą przyjętą do oceny osiągnięć szkolnych był wynik powszechnego sprawdzianu na zakończenie szkoły podstawowej z roku 2013 (sprawdzian przeprowadzany zgodnie z rozporządzeniem Ministra Edukacji Narodowej z dnia 30 kwietnia 2007 r.) wypełnianego na arkuszu egzaminacyjnym (S-1-132) dla uczniów bez dysfunkcji i uczniów $\mathrm{z}$ dysleksją rozwojową. Informacje na temat typu szkoły oraz egzaminu pisanego przez dzieci zostały uzyskane na podstawie historii medycznej. Informacje te zostały każdorazowo zweryfikowane poprzez rozmowę telefoniczną lub kontakt drogą listowną z rodzicem. 


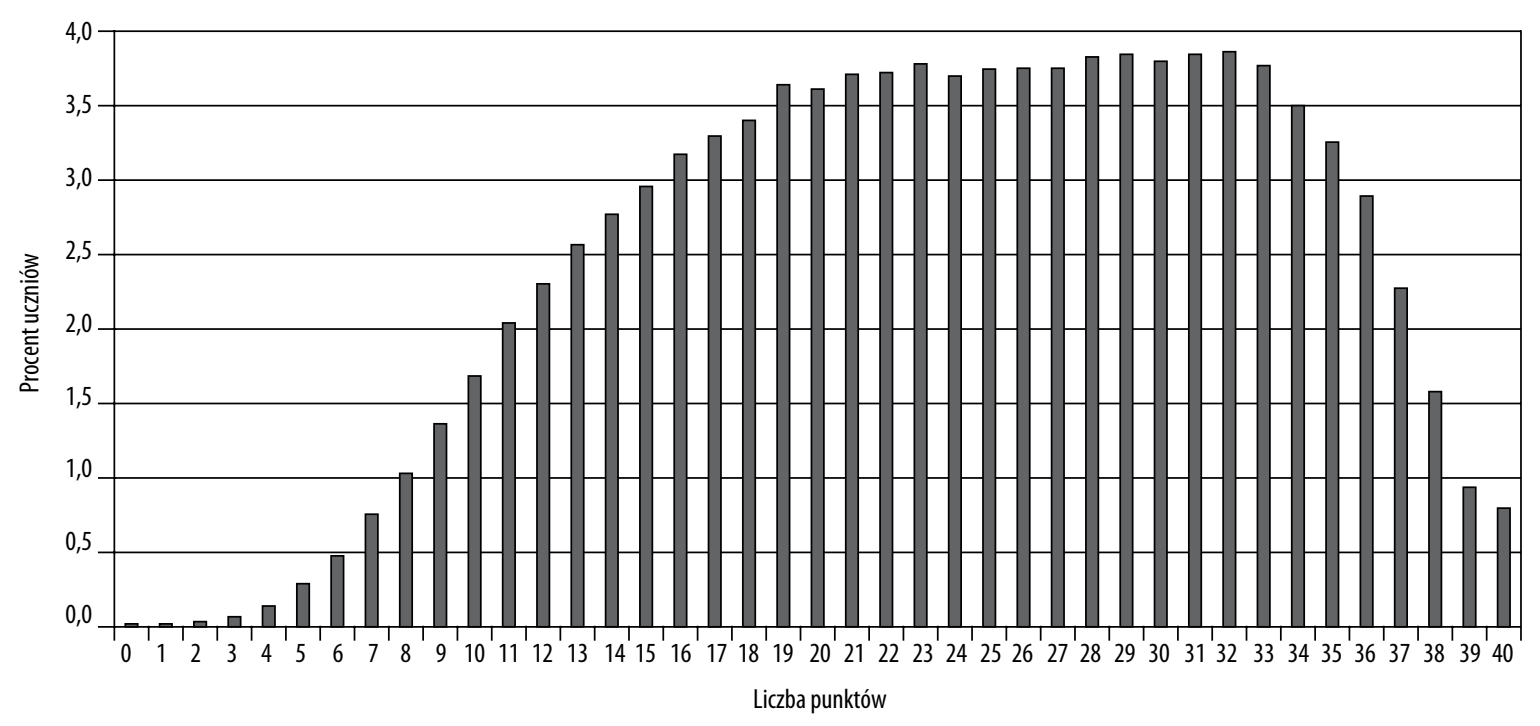

Rycina 1. Rozkład wyników sprawdzianu na zakończenie nauki w szkole podstawowej z roku 2013 w populacji dzieci polskich Figure 1. Distribution of results of school competency test at the end of primary education in 2013 in the population of Polish children

Na mocy Ustawy o systemie oświaty z 7 września $1991 \mathrm{r}$. (Dz.U. z 2004 r., nr 256, poz. 2572, z późn. zm.) uczniowie kończący sześcioletnią szkołę podstawową przystępują do sprawdzianu. Zmiany te doprowadziły do wprowadzenia w polskim systemie oświaty nowego, spójnego dla całego kraju i bardziej zobiektywizowanego systemu oceniania [40]. Obecnie funkcjonują dwa rodzaje oceniania wewnątrzszkolne i zewnętrzne. Ocenianie zewnętrzne jest prowadzone przez instytucje zewnętrzne wobec szkoły Centralną Komisję Egzaminacyjną i Okręgowe Komisje Egzaminacyjne na podstawie ogólnopolskich wymagań egzaminacyjnych, które są zawarte w standardach wymagań stanowiących podstawę przeprowadzania sprawdzianu. Standardy wymagań ustala się po to, aby zapewnić te same wymagania w całym kraju, niezależnie od tego, jaki program nauczania realizowała dana szkoła. Do pomiaru osiągnięć uczniów używa się wystandaryzowanych narzędzi o sprawdzonej rzetelności i trafności. Ten typ oceniania umożliwia niezależność sytuacji egzaminacyjnej przy zapewnieniu anonimowości prac uczniów. Zasady oceniania zewnętrznego określa Rozporządzenie Ministra Edukacji Narodowej z dnia 30 kwietnia 2007 r. w sprawie warunków i sposobu oceniania, klasyfikowania i promowania uczniów i słuchaczy oraz przeprowadzania sprawdzianów i egzaminów w szkołach publicznych [41].

Sprawdzian jest powszechny i obowiązkowy. Przystąpienie do sprawdzianu jest jednym $\mathrm{z}$ warunków ukończenia szkoły. Do sprawdzianu nie przystępują uczniowie z upośledzeniem umysłowym w stopniu umiarkowanym i znacznym. Zgodnie $\mathrm{z}$ wytycznymi wymienionymi w aktualnym dla danego roku szkolnego komunikacie dyrektora Centralnej Komisji Egzaminacyjnej w sprawie sposobu dostosowania warunków i form przeprowadzania sprawdzianu i egzaminu gimnazjalnego do potrzeb uczniów (słuchaczy) ze specjalnymi potrzebami edukacyjnymi, w tym niepełnosprawnych, niedostosowanych społecznie oraz zagrożonych niedostosowaniem społecznym, uczniowie niepełnosprawni mogą skorzystać $\mathrm{z}$ dostosowanej formy testu.
Istnieje również możliwość zwolnienia ucznia z obowiązku przystąpienia do sprawdzianu.

Sprawdzian miał formę pisemną i dla uczniów piszących na arkuszu (S-1-132) przewidziany czas wypełniania testu wynosił 60 minut. Maksymalnie na sprawdzianie można było uzyskać 40 punktów.

\section{Wyniki}

W badanej grupie 16 dzieci realizowało obowiązek szkolny w szkołach ogólnodostępnych i integracyjnych (73\%), a 6 w szkołach specjalnych $(27 \%)$.

Ośmioro dzieci miało opóźnienie w realizacji obowiązku szkolnego (36\% grupy). Do szkół specjalnych uczęszczało 5 z nich, 3 - do szkół ogólnodostępnych i integracyjnych. Wśród tych dzieci było 2 (9\% grupy badanej), u których występowała niepełnosprawność złożona, dodatkowo zdiagnozowane było upośledzenie umysłowe. Byli to uczniowie szkół specjalnych.

W roku szkolnym 2012/2013 szkołę podstawową ukończyło, realizując obowiązek szkolny zgodnie $\mathrm{z}$ wiekiem metrykalnym, i przystąpiło do sprawdzianu 14 dzieci (63\% badanej grupy). Z grupy tej sprawdzian na formularzu dla dzieci bez dysfunkcji pisało 7 dzieci (31,5\% badanej grupy). Pięcioro dzieci uczęszczało do szkół ogólnodostępnych, a dwoje do szkół integracyjnych. Tyle samo dzieci (7) pisało sprawdzian na formularzu dostosowanym dla niesłyszących i słabosłyszących. W tej grupie 3 dzieci uczęszczało do szkół ogólnodostępnych, 3 do szkół integracyjnych, a 1 dziecko uczyło się w placówce specjalnej.

Oceniając możliwość przystąpienia przez dzieci z głębokim niedosłuchem prelingwalnym, którym wszczepiono implant ślimakowy przed ukończeniem 3 roku życia, do sprawdzianu na zakończenie nauki w szkole podstawowej na takich samych zasadach jak dzieci bez dysfunkcji, 
Tabela 1. Rozkład wyników sprawdzianu uczniów bez dysfunkcji z roku 2013 i z grupy badawczej na skali staninowej Table 1. Distribution of results of a school competency test conducted in 2013 in children with no dysfunctions and of the tested group - stanine scores

\begin{tabular}{|c|c|c|c|c|}
\hline Stanin & & $\begin{array}{l}\text { Przedział wyników } \\
\text { (0-40 pkt) }\end{array}$ & $\begin{array}{l}\text { Procent wyników } \\
\text { w grupie kontrolnej }\end{array}$ & $\begin{array}{l}\text { Wyniki dzieci z głębokim niedosłuchem } \\
\text { korzystających z implantu ślimakowego } \\
\text { wszczepionego im przed ukończeniem } \\
3 \text { roku życia }\end{array}$ \\
\hline 1 & najniższy & $0-9$ & 4,1 & - \\
\hline 2 & bardzo niski & $10-12$ & 6,0 & - \\
\hline 3 & niski & $13-16$ & 11,5 & - \\
\hline 4 & niżej średni & $17-21$ & 17,7 & - \\
\hline 5 & średni & $22-27$ & 22,5 & $\begin{array}{l}\text { Dziewczynka nr } 2-26 \\
\text { Chtopiec nr 5-26 }\end{array}$ \\
\hline 6 & wyżej średni & $28-31$ & 15,3 & $\begin{array}{c}\text { Dziewczynka nr } 3-31 \\
\text { Chłopiec nr } 2-30 \\
\text { Chłopiec nr } 1-28\end{array}$ \\
\hline 7 & wysoki & $32-35$ & 14,4 & Dziewczynka nr $4-34$ \\
\hline 8 & bardzo wysoki & $36-37$ & 5,2 & - \\
\hline 9 & najwyższy & $38-40$ & 3,3 & Dziewczynka nr $1-40$ \\
\hline
\end{tabular}

stwierdzono istnienie takiej możliwości u prawie $32 \%$ dzieci $\mathrm{z}$ badanej grupy.

Drugim celem badania było porównanie osiągnięć szkolnych dzieci korzystających z implantu ślimakowego z osiągnięciami dzieci bez dysfunkcji.

Uzyskano następujące wyniki. Na tle rozkładu wyników sprawdzianu na zakończenie nauki w szkole podstawowej z roku 2013 w populacji dzieci bez dysfunkcji (rycina 1), wyniki w grupie badanej przedstawiają się następująco: jedno dziecko uzyskało wynik maksymalny 40 punktów, taki wynik uzyskało poniżej $1 \%$ całej populacji dzieci piszących test w roku 2013; jedno dziecko uzyskało 34 punkty, podobnie jak $3,5 \%$ populacji piszącej test, pięcioro dzieci uzyskało wynik na poziomie od 31 do 26 punktów, który mieści się między 3,5\% a 4\% populacji ogólnej [42].

Rozkład wyników w grupie dzieci korzystających z implantu ślimakowego na skali staninowej w porównaniu z grupą dzieci piszących sprawdzian w roku 2013 ilustruje tabela 1. Skala staninowa stosowana w pomiarze dydaktycznym odpowiada na pytanie, jaką pozycję zajmuje wynik osiągnięty przez ucznia/absolwenta na tle wyników osiągniętych przez całą badaną populację. Skala staninowa powstaje przez transformację wyników surowych na wyniki wyrażane w liczbach naturalnych od 1 do $9, \mathrm{z}$ zachowaniem zasady, że wszystkie przekształcone wyniki łącznie mają przed jakąkolwiek selekcją rozkład normalny o średniej 5 i odchyleniu standardowym 1,96 [43]. Odpowiednim surowym wynikom testowania (nie uczniom) z poszczególnych stanin przyporządkowuje się określenia: najniższy, bardzo niski, niski, niżej średni, średni, wyżej średni, wysoki, bardzo wysoki, najwyższy.

Wśród dzieci z grupy badanej wynik 40 punktów uzyskany przez Dziewczynkę nr 1 znajduje się w 9 staninie jako wynik najwyższy (4\% ogółu wyników). 34 punkty uzyskane przez Dziewczynkę nr 4 to 7 stanin, co oznacza wynik wysoki (12\% ogółu wyników). Punktacja od 31 do 28 pkt, uzyskana przez Dziewczynkę nr 3, Chłopca nr 2 i Chłopca nr 1, należy do staninu 6. Są to wyniki powyżej średniej i stanowią 17\% wyników ogółu. Dwie osoby: Dziewczynka nr 2 oraz Chłopiec nr 5 z 26 punktami znalazły się na 5 staninie, określanym jako średni, gdzie znajduje się 20\% wyników ogółu. Żadne dziecko nie uzyskało wyniku poniżej średniego [42].

\section{Dyskusja}

Jednym z najważniejszych celów leczenia i rehabilitacji dzieci niepełnosprawnych słuchowo jest wyrównanie szans edukacyjnych tej grupy w stosunku do dzieci z normą słuchową, tak by system edukacyjny mógł przygotować te osoby do pełnienia ról zawodowych [44]. Postępowanie rewalidacyjne (naprawcze), jakiemu poddawane są osoby z wadą słuchu, jest ukierunkowane na przywracanie sprawności uszkodzonego zmysłu słuchu poprzez umożliwienie korzystania z posiadanych resztek słuchowych dzięki właściwie dobranemu aparatowi słuchowemu bądź pobudzanie nerwu słuchowego przez system implantu ślimakowego [45].

Obserwowana wśród rodziców dzieci niepełnosprawnych tendencja do wyboru edukacji włączającej jest widoczna także wśród rodziców dzieci głuchych i słabosłyszących W ciągu ostatnich 12 lat liczba uczniów z wadą słuchu w szkołach specjalnych spadła o ponad $50 \%$, natomiast widoczny jest wyraźny trend o tendencji wzrostowej do nauki dzieci niesłyszących i słabosłyszących poza szkolnictwem specjalnym [46-48]. W badanej grupie dzieci implantowanych przed 3 rokiem życia aż 73\% uczniów realizowało obowiązek szkolny w szkołach ogólnodostępnych i integracyjnych, z czego 52\% w szkołach ogólnodostępnych i $21 \% \mathrm{w}$ integracyjnych. Uzyskany odsetek dzieci uczących się w szkołach ogólnodostępnych jest wyższy od raportowanego przez Archbold (2002). Analizując sytuację 
edukacyjną 42 dzieci implantowanych w wieku od 1,8 do 7,8 lat, autorka wykazała, że $38 \%$ dzieci uczyło się w szkołach ogólnodostępnych, 57\% było w klasach specjalnych, a 5\% w szkołach dla głuchych [49]. Z uwagi na to, że w Anglii klasy specjalne utworzone zostały w szkołach masowych w myśl idei szkolnictwa integracyjnego, w szkołach specjalnych uczył się znacznie mniejszy odsetek dzieci niż $\mathrm{w}$ analizowanej grupie. Wyniki podobne do przedstawionych w niniejszym badaniu uzyskali De Raeve i Lichtert (2012), którzy podają, że w regionie flamandzkim Belgii $46 \%$ dzieci korzystających z implantu ślimakowego i uczących się w szkole podstawowej uczęszczało do placówek ogólnodostępnych [50]. W badanej grupie dzieci, u których nie występowały dodatkowe niepełnosprawności, $80 \%$ z nich uczęszczało do szkół ogólnodostępnych i integracyjnych, pozostałe $20 \%$ uczyło się w szkołach specjalnych.

Ze względu na to, że analizie poddano sytuację edukacyjną dzieci wcześnie implantowanych, z jednego rocznika uzyskane proporcje procentowe mogą nie być takie same w kolejnych rocznikach. Mogą jednak służyć do wyznaczenia ogólnych prawidłowości. Na ich podstawie można wnioskować, czego można się spodziewać w zakresie realizowania obowiązku szkolnego na poziomie szkoły podstawowej przez dzieci implantowane przed 3 rokiem życia.

Nie należy upatrywać jednak w rodzaju placówki, do której uczęszcza dziecko, jedynego źródła jego sukcesu czy porażki, gdyż zgodnie $\mathrm{z}$ obowiązującym prawem to rodzic dziecka decyduje o wyborze placówki kształcenia, a do szkół specjalnych częściej uczęszczają dzieci z większymi problemami komunikacyjnymi i dodatkowymi obciążeniami rozwojowymi [3].

W dużej mierze zróżnicowanie indywidualne osiągnięć szkolnych na wczesnym etapie edukacji jest związane z cechami biologicznymi uczniów i środowiskiem rodzinnym, z którego pochodzą [51]. Spionek podkreśla deficyty rozwojowe uczniów w zakresie funkcji wzrokowych, słuchowych, percepcyjno-motorycznych, opóźnienia rozwoju ruchowego czy zaburzenia mowy jako mające szczególny wpływ na osiągnięcia szkolne uczniów [52]. W cytowanych wcześniej badaniach Kirejczyka (1970) z roku 1962 i 1967, dotyczących nauczania dzieci głuchych w szkołach dla słyszących, średnie oceny szkolne w badanej grupie kształtowały się na poziomie oceny nie niższej niż dostateczny plus [35]. Autor wskazywał czynniki warunkujące efektywność uczenia się dzieci głuchych w szkołach dla słyszących takie jak: selekcja uczniów głuchych przed przyjęciem do placówki ogólnodostępnej, dodatkowe przygotowanie do nauki wynikające $\mathrm{z}$ dużego zaangażowania rodziców dziecka oraz zapewnienie odpowiednich warunków i ewentualnej pomocy w nauce. Podobnie Góralówna (1992) w publikacji poprzedzającej erę stosowania implantów w leczeniu głuchoty wskazuje czynniki mogące decydować o powodzeniu ucznia niesłyszącego w szkole ogólnodostępnej, takie jak: przygotowanie przedszkolne, opanowanie języka, poziom intelektualny, gotowość do podejmowania dodatkowych prac, odporność na niepowodzenia [30]. W badanej w ramach niniejszej pracy grupie siedmiorga dzieci prelingwalnie głuchych, korzystających z implantu ślimakowego wszczepionego im przed ukończeniem trzeciego roku życia, większość z nich uczyła się w placówkach ogólnodostępnych, gdzie warunki pod względem liczebności klasy czy dostępu do wsparcia ze strony nauczyciela są bardziej ograniczone niż w placówkach specjalnych. Dzieci te realizowały obowiązek szkolny zgodnie z wiekiem kalendarzowym, bez wydłużonego okresu przygotowawczego do rozpoczęcia nauki. Decyzją rodziców zostały one umieszczone w placówkach ogólnodostępnych, bez konieczności formalnego wykazania spełnienia wymogów umożliwiających podjęcie nauki w tego typu placówce. Można dostrzec zachodzącą zmianę w możliwościach funkcjonowania w szkolnictwie ogólnodostępnym dzieci głuchych korzystających z implantu ślimakowego. Obserwowany w ciągu ostatnich lat trend w kierunku uczestnictwa tych dzieci w szkolnictwie masowym doprowadzi prawdopodobnie wkrótce do zwiększenia liczby tych dzieci piszących egzamin na formularzu standardowym i do możliwości oceny czynników warunkujących sukces edukacyjny tej grupy [50]. Dalsze badania na większym materiale pozwolą na poszerzenie i ugruntowanie wiedzy w tym zakresie.

Porównując osiągnięcia szkolne na zakończenie nauki w szkole podstawowej, oceniane z wykorzystaniem sprawdzianu przeprowadzanego zgodnie $\mathrm{z}$ rozporządzeniem Ministra Edukacji Narodowej z dnia 30 kwietnia 2007 r., u dzieci z głębokim prelingwalnym niedosłuchem, korzystających z implantu ślimakowego wszczepionego im przed ukończeniem 3 roku życia, i dzieci bez dysfunkcji, stwierdzono, że wyniki dzieci z grupy badanej mieściły się w przedziałach od średniego do najwyższego na skali staninowej. Wyniki te można określić jako satysfakcjonujące z uwagi na to, że $40 \%$ dzieci ze słuchem prawidłowym osiągnęło wyniki poniżej przedziału średniego. Aby podjąć próbę odpowiedzi na pytanie, o czym świadczą dobre osiągnięcia szkolne zidentyfikowanych siedmiorga dzieci implantowanych, które pisały sprawdzian na formularzu regularnym, należy dokładnie przeanalizować, w jaki sposób została wyłoniona grupa badana. $\mathrm{Z}$ uwagi na przyjęte kryteria do grupy tej zakwalifikowano wszystkie dzieci implantowane przed 3 rokiem życia i urodzone w roku 2000. Zakładając, że dzieci te nie powinny różnić się w sposób znaczący od dzieci urodzonych w późniejszych latach, można przyjąć, że analiza ich sytuacji edukacyjnej dostarczy ważnych informacji o populacji dzieci wcześnie implantowanych. Zidentyfikowana grupa siedmiorga dzieci stanowi 44\% dzieci uczęszczających do szkół ogólnodostępnych i integracyjnych w badanej grupie. Wśród dzieci uczęszczających do tych szkół 19\% dzieci miało odroczony obowiązek szkolny, a 37\% pisało egzamin na formularzu dostosowanym. Ich osiągnięcia szkolne nie zostały porównane $\mathrm{z}$ osiągnięciami dzieci bez dysfunkcji. A zatem 44\% dzieci implantowanych uczęszczających do szkół ogólnodostępnych i integracyjnych osiągnęło wyniki co najmniej w 5 staninie wyznaczonym dla dzieci bez dysfunkcji.

Obecny zakres dostosowania warunków sprawdzianu dla uczniów niesłyszących i słabosłyszących opiera się na medycznym podziale głuchoty, a nie na jej wymiarze funkcjonalnym. Dzieci niesłyszące i słabosłyszące posiadające orzeczenie o niepełnosprawności oraz o specjalnych potrzebach edukacyjnych mogą korzystać z dostosowanej formy arkusza sprawdzianu. Wersja ta jest inna w treści w stosunku do sprawdzianu dla dzieci słyszących, co może wskazywać na obniżanie poziomu wymagań, a nie na dostosowywanie warunków dla wyrównania szans [53]. 
Alternatywną drogą wspomagania, przy zachowaniu tych samych standardów, jakie obowiązują dla dzieci bez dysfunkcji, mogłoby być wydłużenie czasu pisania sprawdzianu na formularzu regularnym. W przeprowadzonym badaniu w przypadku ponad $30 \%$ dzieci implantowanych przed ukończeniem 3 roku życia uzyskane przez te dzieci wyniki sprawdzianu potwierdziły, że podjęta przez rodziców decyzja o rezygnacji z dostosowanej formy testu była trafna.

Ograniczenia prezentowanego badania prowadzonego metodą kliniczno-kontrolną nie pozwalają na odniesienie uzyskanych wyników procentowych do całej populacji dzieci wcześnie implantowanych. Dostarczają one jednak cennych informacji o sytuacji edukacyjnej pierwszej grupy dzieci prelingwalnie głuchych, którym wszczepiono implant ślimakowy przed 3 rokiem życia, a zatem w okresie największej plastyczności drogi słuchowej.

\section{Wnioski}

1. Udział dzieci prelingwalnie głuchych, którym wszczepiono implant przed 3 rokiem życia, w szkolnictwie ogólnodostępnym i integracyjnym przeważa nad pobieraniem przez te dzieci nauki w szkolnictwie specjalnym.

2. Mimo możliwości skorzystania $\mathrm{z}$ formularza sprawdzianu dostosowanego dla uczniów niesłyszących i słabosłyszących część rodziców wybiera formularz dla uczniów bez dysfunkcji.

3. Dzieci prelingwalnie głuche, które korzystają z implantu ślimakowego wszczepionego im przed ukończeniem 3 roku życia i decyzją rodziców przystępują do sprawdzianu na warunkach takich samych jak dzieci bez dysfunkcji, uzyskują w tym sprawdzianie satysfakcjonujące wyniki.

4. Wyniki zebrane w ramach niniejszej pracy umożliwiły przeprowadzenie pierwszych analiz dotyczących korzyści z interwencji medycznej polegającej na wczesnej implantacji u dzieci głuchych w kontekście osiąganych przez nie wyników w nauce po ponad 10 latach korzystania z systemu implantu ślimakowego.

Projekt został sfinansowany ze środków Narodowego Centrum Nauki przyznanych na podstawie decyzji numer UMO-2013/09/N/ NZ7/03586.

\section{Piśmiennictwo:}

1. Ślebioda R. Kierunek i poziom wykształcenia oraz aktywność zawodowa osób z niepełnosprawnością. Niepełnosprawność - zagadnienia, problemy, rozwiązania, 2012; 2(3): 107-30.

2. Golinowska S. Polityka społeczna - koncepcje - instytucje koszty. Warszawa: Poltex; 2000.

3. Grabias S: Perspektywy opisu zaburzeń mowy. W: Grabias S, red. Zaburzenia mowy. Lublin: Wydawnictwo Uniwersytetu Marii Curie-Skłodowskiej; 2002, s. 11-43.

4. Kobosko J. Psychologiczne implikacje głuchoty dziecka w rodzinie i środowisku szkolnym. W: Edukacja głuchych. Warszawa: Rzecznik Praw Obywatelskich; 2014, s. 44-66.

5. Skarżyński H, Lorens A, Piotrowska A. Wszczepy ślimakowe W: Śliwińska-Kowalska M. Audiologia Kliniczna. Łódź; Mediton; 2005; s. 429-42.

6. Skarżyński H, Janczewski G, Geremek A, Niemczyk K, Klasek O, Kochanek K. Pierwszy wszczep ślimakowy w Polsce. Otolaryngol Pol, 1993; 47(5): 427-34.

7. Eisenberg LS, House WF. Initial experience with the cochlear implant in children. Ann Otol Rhinol Laryngol Suppl, 1982; 91(2 Pt 3): 67-73.

8. Geremek A, Skarżyński H, Szuchnik J. Program implantów ślimakowych u dzieci - stan obecny. Audiofonologia, 1998; XIII: 281.

9. Lenneberg EH. Biological Foundations of Language. New York: Wiley; 1967.

10. Blatchley BJ, Williams JE, Coleman JR. Age-dependent effects of acoustic deprivation on spherical cells of the rat anteroventral cochlear nucleus. Exp Neurol, 1983; 80(1): 81-93.

11. Skarżyński H, Żarowski A. Zmiany w uchu wewnętrznym w aspekcie długotrwałej stymulacji. W: Kobosko J, red. Bliżej życia. Materiały dla rodziców dzieci i młodzieży z wadą słuchu. Warszawa: Stowarzyszenie Przyjaciół Osób Niesłyszących i Niedosłyszących „Człowiek-Człowiekowi”; 2001, s. 70-7.

12. Harrison RV, Panesar J, EI-Hakim H, Abdoek M, Mount RL, Papsin B. The effects of age of cochlear implantation on speech perception in prelingually deaf children. Scan Audio Suppl, 2001; 53, 73-8.
13. Skarżyński H, Góralówna M, Janczewski G, Geremek A. Wybrane problemy w stosowaniu implantów ślimakowych. Otolaryngol Pol, 1993; 47(3): 217.

14. Yoshinaga-Itano C, Sedey AL, Coulter DK, Mehl AL. Language of early- and later-identified children with hearing loss. Pediatrics, 1998; 102(5): 1161-71.

15. Luxford WM, Winter M, Eisenberg L. Evaluation of the 12 to 18 -month-old cochlear implant candidate. The $6^{\text {th }}$ International Cochlear Implant Conference, 2002.

16. Dolan-Ash S. Speech perception and language abilities of children implanted under the age of two year. The $6^{\text {th }}$ International Cochlear Implant Conference, 2002.

17. Edwards J, Willis S, Tyszkiewicz E, Henderson L, Ramsden R. Cochlear implants in the under 2's and under 3's. The $6^{\text {th }}$ International Cochlear Implant Conference, 2002.

18. Parisier SC, Chute PM, Popp AL. Cochlear implant results in children under 20 months of age. The $6^{\text {th }}$ International Cochlear Implant Conference, 2002.

19. Kirk KI, Miyamoto RT, Lento CL, Ying E, O’Neill T, Fears B. Effects of age at implantation in young children. Ann Otol Rhinol Laryngol Suppl, 2002; 189: 69-73.

20. Sharma A, Dorman M, Spahr A. A sensitive period for the development of the central auditory system in children with cochlear implants. Ear Hear, 2002; 23: 532-9.

21. Sharma A, Dorman M, Kral A. The influence of a sensitive period on central auditory development in children with unilateral and bilateral cochlear implants. Hear Res, 2005; 203: $134-43$.

22. Kral A, Sharma A. Developmental neuroplasticity after cochlear implantation. Trends Neurosci, 2012; 35(2): 111-22.

23. Gordon KA, Jiwani S, Papsin BC. Benefits and detriments of unilateral cochlear implant use on bilateral auditory development in children who are deaf. Front Psychol, 2013; 4: 719: $1-14$.

24. Govaerts P, De Beukelaer C, Daemers K, De Ceulaer G, Yperman $\mathrm{M}$, Somers $\mathrm{T}$ i wsp. Outcome of cochlear implantation at different ages from 0 to 6 years. Otol Neurotol, 2002; 23: $885-90$. 
25. May-Mederake B. Early intervention and assessment of speech and language development in young children with cochlear implants. Int J Pediatr Otorhinolaryngol, 2012; 76: 939-46.

26. Holman M, Carlson M, Driscoll C, Grim K, Petersson R, Sladen $\mathrm{D}$ i wsp. Cochlear implantation in children 12 months of age and younger. Otol Neurotol, 2013; 34: 251-8.

27. Geremek-Samsonowicz A, Kłonica LK, Rostkowska J, Piełuć M, Skarżyński H. Model postępowania diagnostyczno-terapeutycznego wobec niemowlęcia i jego rodziny przed operacją wszczepienia implantu ślimakowego. Nowa Audiofonologia, 2012; 1(1): 119-25.

28. Summerfield A, Marshall D. Paediatric cochlear implantation and health-technology assessment. Int J Pediatr Otorhinolaryngol, 1999; 47(2): 141-51.

29. Kuligowska K. Doskonalenie lekcji. Warszawa: WSiP; 1984.

30. Góralówna M. Szkolne sprawy naszych dzieci. W: Poradnik dla rodziców dzieci z wadami słuchu. Warszawa; 1992, 3, s. 10.

31. Spencer LJ, Gantz BJ, Knutson JF. Outcomes and achievement of students who grew up with access to cochlear implants. Laryngoscope, 2004; 114(9): 1576-81.

32. Punch R, Hyde MB. Communication, psychosocial, and educational outcomes of children with cochlear implants and challenges remaining for professionals and parents. Int. J. Otolaryngol, 2011; 2011: 573280.

33. Mukari SZ, Lai NL, Hanizam AG. Educational performance of pediatric cochlear implant recipients in mainstream classes. Int J Pediatr Otorhinolaryngol, 2007; 71(2): 231-40.

34. Kosmalowa J, Szuchnik J. Funkcjonowanie szkolne pacjentów implantowanych objętych programem EARS. Audiofonologia, 2000; XVIII: 46-7.

35. Kirejczyk K. Kryzys systemu szkolnictwa specjalnego dla głuchych - przyczyny i próby zwalczania kryzysu W: Kirejczyk K, red. Z zagadnień surdopedagogiki. Warszawa: Nasza Księgarnia; 1970 , s. 7-24.

36. Klichowski M, Przybyła M. Cyborgizacja edukacji - próba konceptualizacji. Studia Edukacyjne, 2013; 24: 143-53.

37. Jakubczyk M, Niewada M. Elementy oceny organizacji i wyników badań klinicznych. Warszawa: Centrum Medyczne Kształcenia Podyplomowego; 2011.

38. Miller FG. The ethical challenges of human research: Selected essays. Oxford: University Press; 2012.

39. Piotrowska A, Lorens A, Szuchnik J, Wojewódzka B, Kosmalowa J, Skarżyński H. Procedura przedoperacyjna kwalifikacji do wszczepienia implantu ślimakowego stosowana w Instytucie Fizjologii i Patologii Słuchu w Warszawie. Audiofonologia, 2001; XX: 43-50.
40. Dz.U. z 2004 r., nr 256, poz. 2572, z późn. zm.

41. Dz.U. z 2007 r., nr 83, poz. 562.

42. Centralna Komisja Egzaminacyjna. Osiągnięcia uczniów kończących szkołę podstawową w roku 2013. Sprawozdanie ze sprawdzianu. Warszawa: Centralna Komisja Egzaminacyjna; 2013.

43. Guilford JP. Podstawowe metody statystyczne. Warszawa: PWN; 1964.

44. Sorkin DL, Zwolan TA. Trends in educational services for children with cochlear implants. W: Miyamoto RT, red. Cochlear Implants: Proceedings of the VIII International Cochlear Implant Conference, Amsterdam, 2004; 417-21.

45. Eckert U. Pedagogika niesłyszących i niedosłyszących - surdopedagogika. W: Dykcik W, red. Pedagogika specjalna. Poznań: Wydaw. Naukowe UAM; 2009.

46. Sak M. W poszukiwaniu optymalnego modelu edukacji osób głuchych i słabo słyszących w Polsce. W: Twardowska E, Kowalska $M$, red. Edukacja niesłyszących (publikacja konferencyjna). Łódź: PZG Oddział łódzki; 2011, s. 111-22.

47. Oświata i wychowanie w roku szkolnym 2009/2010. Warszawa: GUS; 2010.

48. Zgoda M, Lorens A, Skarżyński H. Partial Deafness Treatment in children: educational settings after 5 to 7 years of cochlear implant use. Journal Hearing Science, 2012; 2(2), 70-4.

49. Archbold SM, Nikolopoulos TP, Lutman ME, O’Donoghue GM. The educational settings of profoundly deaf children with cochlear implants compared with age-matched peers with hearing aids: implications for management. Int J Audiology, 2002; 41(3): 157-61.

50. De Raeve L, Lichtert G. Changing trends within the population of children who are deaf or hard of hearing in Flanders (Belgium): effects of 12 years of universal newborn hearing screening, early intervention, and early cochlear implantation. Volta Review, 2012; 112(2): 131-48.

51. Jasińska A, Modzelewski M. Międzyszkolne zróżnicowanie wyników nauczania po pierwszym etapie kształcenia. XIX Konferencja Diagnostyki Edukacyjnej, Gniezno; 2013.

52. Karpińska A. Drugoroczność - pedagogiczne wyzwanie dla współczesności. Białystok: Trans Humana; 1999.

53. Raszeja-Ossowska I. Młodzi-Niepełnosprawni. Sytuacja społeczna i zawodowa. Warszawa: Fundacja Pomocy Matematykom i Informatykom Niepełnosprawnym Ruchowo; 2012. 